\title{
IS THE TRADITIONAL KURDISH MALE BELT A PREVENTIVE OF LOW BACK PAIN AND SCIATICA?: A CASE CONTROL STUDY
}

\author{
WAHID M. HASSAN, MBCHB, FIBMS (ORTHO), FISKSAA \& FIAS (INDIA)* \\ SAMIM A AL-DABBAGH, MBCHB, DTM \& H, D.PHIL, FFPH** \\ REDIR T HASSAN, BVMS, MSC, (UK) $* * *$ \\ MOHAMMAD TAHIR RASOOL, MBCHB, MRCP, FRCP (UK)****
}

\section{Submitted 30 October 2019; accepted 15 February 2020}

\begin{abstract}
Background: Low back pain (LBP) is a common complaint in general practice. There are conflicting reports about the benefit of supportive belts in the treatment and prevention of LBP. The aim of this study is to identify any possible preventive effect of the traditional male Kurdish belt (Sheteck) on LBP and sciatica.

Method: A case-control study was designed. A specially designed questionnaire was developed and filled for participants in Duhok governorate in the Kurdistan region of Iraq. Cases were patients presented with LBP, while control was aged-matched ( \pm 5 years) apparently healthy individuals who had no LBP at least in the previous 10 years. Statistical Package for the Social Sciences (SPSS) was used for data management. Chi-square, Fisher's exact, was used for calculation of the statistical significance. The mean, standard deviation $( \pm \mathrm{SD})$, and Odd ratios were used with some clinical and general criteria.
\end{abstract}

Results: A total of 149 cases and 100 controls were participated in this study. The mean ages of cases and controls were $51.4( \pm 13.28)$ and $59.22( \pm 12.6)$, respectively. The mean duration of LBP among cases was 5.54 years $( \pm 6.17)$, with $47 \%$ of them have pain radiating to the leg, and around $42.9 \%$ had involved in the sciatic nerve. None of the controls had LBP or sciatica. The habit of wearing Sheteck was significantly negatively associated $(\mathrm{P}<0.001)$ with the absence of LBP with an Odd ratio of 0.23 . The study also found that the period and duration of wearing Sheteck per day were significantly longer $(\mathrm{P}<0.001)$ in controls in comparison to cases. Finally, the Sheteck was almost completely protective for sciatica among cases.

Conclusion: Traditional Kurdish male belt (Sheteck) is highly protective for LBP and Sciatica.

Duhok Med J 2020; 14 (2): 10-19

Keywords: LBP, Sciatica, Supportive belt and Sheteck

T ow back pain is a very common health problem worldwide especially in the low and middle-income countries. The LBP may be acute or chronic in nature caused by several medical conditions. The majority of acute low back pain is mechanical in nature due to sprains and strains. Chronic LBP, on the other hand, is most commonly attributed to sciatica, which a radiculopathy condition caused by compression, inflammation and/or injury to the spinal nerve roots ${ }^{1-6}$.

In the USA about half (55\%) of LBP cases were due to sciatica ${ }^{7}$. Such patients cannot be involved in leisure and sports activities, in addition to the sleeping disturbances, which lead to anxiety and depression ${ }^{8}$.

The LBP has been associated with obesity, aging, posture, lifting heavy material, sudden movements, and psychological

\footnotetext{
* Assis. Professor, Department of Surgery, College of Medicine, University of Duhok, Kurdistan Region, Iraq.

**Professor, Department of Community medicine, College of Medicine, University of Duhok, Kurdistan Region, Iraq.

***Assis. Lecturer, Department of Anatomy, Biology and Histology, College of Medicine, University of Duhok, Kurdistan Region, Iraq.

****Assistant Professor, Department of Medicine, College of Medicine, University of Duhok, Kurdistan Region, Iraq. Correspondence author: Redir T Hassan, redir.hassan@uod.ac, Mobil +964 7504736724
} 
factors. The health care system should develop and provide challenges to educate the patients on the prevention of LBP by reducing weight, special movements in lifting heavy material (squatting), and increase physical activity levels ${ }^{9,10}$. Recently, psychological factors have been incriminated to contribute to the etiology of $\mathrm{LBP}^{11,12}$. A new study found that the patients were more satisfied if the physiotherapy was combined with psychological support ${ }^{9,13}$.

Different health care treatments have been used, including chiropractic, physiotherapy, complementary, and alternative medicines therapies. People with LBP believed that they would become better and more satisfied with chiropractic therapy, but researchers found that this has not relieved the patient's pain for a long time $^{14,15}$. However, chiropractic therapy is considered one of the most popular and comfortable management of LBP disorder in male patients who have high income and those who do not want to use medications for treatment ${ }^{1,16}$.

Supportive belts have been used frequently in the management and prevention of LBP. The results from different studies gave conflicting results for its benefit in relieving and reducing pain or preventing $\mathrm{LBP}^{17-19}$. A traditional Kurdish belt (Sheteck) has been used for generations by males as an accessory for traditional Kurdish clothes. This belt is composed of textile material from 6 to 10 meters with or without nodes. Nowadays, few people are wearing traditional clothes and the belt as new Kurdish generations are affected by the globalization of a new style of fashion.
The aim of this study is to measure any possible preventive effect of traditional male Kurdish belt on LBP and sciatica.

\section{MATERIAL AND METHODS}

A case-control study was designed. Scientific and ethical approvals were obtained from the University of Duhok, College of Medicine, and Duhok General Directorate of Health. A total of 149 male cases and 100 controls were collected. The study took place in the orthopedic department of the emergency teaching hospital in Duhok, Kurdistan region of Iraq, between June 2017- June 2019. The cases were patients presented with LBP for more than 6 months. All were examined clinically by a specialist orthopedic surgeon for the presence of sciatica using a straight leg raising test.

Controls were selected from relatives accompanied by patients and employees of the hospital. All gave no history of LBP for at least 10 years. The cases were agematched $( \pm 5$ years $)$ with controls. All controls were also examined clinically for sciatica by the same specialist.

A specially designed questionnaire was developed and filled for cases and control. In addition to the general information regarding age, occupation, the habit and period, and hours per day of wearing Sheteck were asked. Also, data were collected regarding the duration of the pain, radiation of the pain to the leg, the severity of the pain, and limitation activity. The weight and height were measured for cases and controls for calculation of BMI. All were weighted with a light clothed and with no shoes. Involvement of Sciatica was stated as yes or no in the questionnaire after the clinical examination. 
Furthermore, the Sheteck is two types

Badinani and Sorani. The Badinani has a textile length of about 7-10 meters with 11.5 meters width. The textile then folded into around $5 \mathrm{~cm}$ folds and put in layers, usually arranged with nodes, starting from just above the umbilicus going down to the upper margin of the ilio-sacral joint with a width of about $20 \mathrm{~cm}$. (figure1). The Sorani type of belt is similar but with a shorter textile length not exceeding 6 meters arranged with no nodes and usually wear from umbilicus going downs to almost 15 $\mathrm{cm}$. (figure 2)

Statistical Package for the Social Sciences (SPSS) version 22 was used for data management and statistical analysis in both cases and controls. Chis square, Fisher's exact were used for calculation of the statistical significance. Clinical and general criteria in both cases and controls were presented as mean and standard deviation $( \pm \mathrm{SD}) . \quad P$-value $<0.05$ was considered significant.

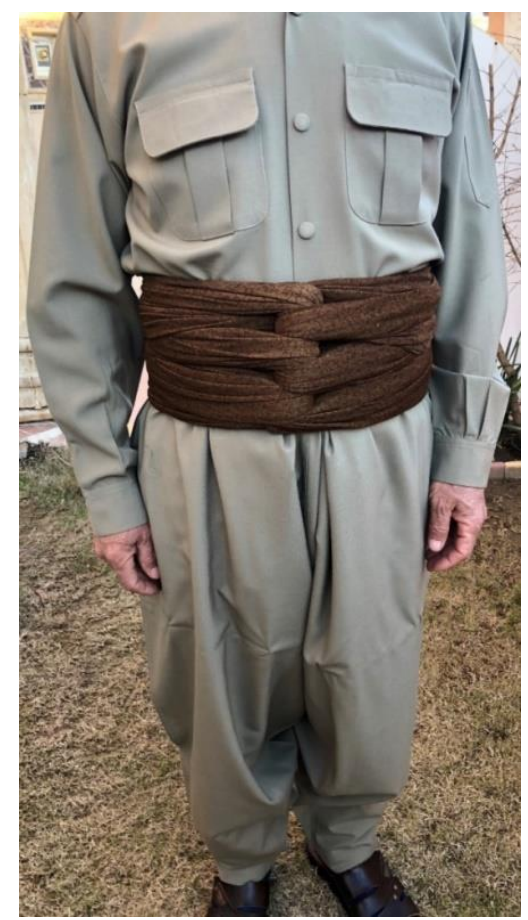

Figure 2: Sheteck Badinani type

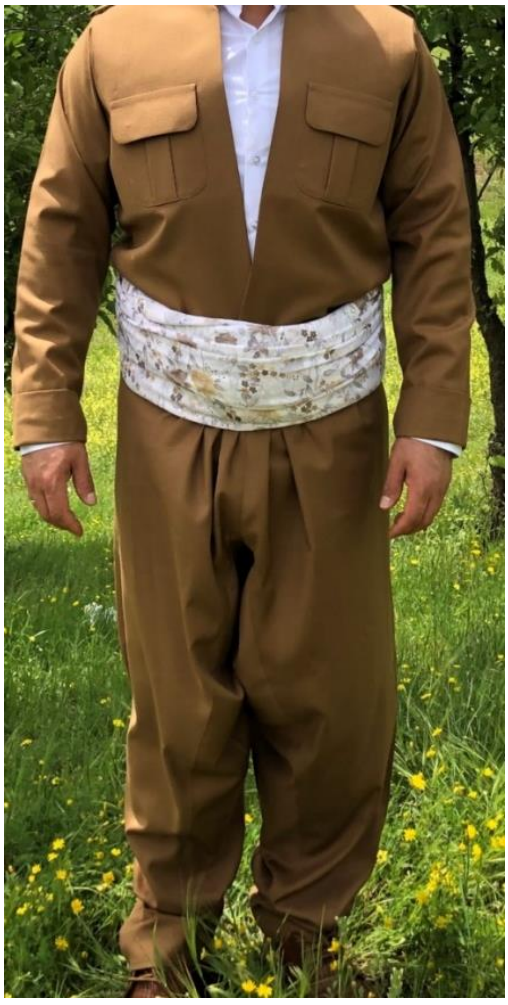

Figure 2: Sheteck Sorani type

\section{RESULT}

A total of 149 cases and 100 controls were selected. The average age for cases was 51.4( \pm 13.28$)$, which was significantly lower than that of controls 59.22( \pm 12.6$)$, $(p<0.001)$. Regarding occupation, there were no significant differences between cases and controls. The mean duration of back pain among cases was $5.54( \pm 6.17)$ years, with $47.6 \%, 44.3 \%$ and $8.1 \%$ have mild, moderate, and severe pain, respectively. A total of $47 \%$ of the cases have the pain radiation to the leg, and $36.9 \%$ have the limitation of activity. Around $42.9 \%$ of the cases were involved with sciatica. None of the Controls had LBP or sciatica.

The habit of wearing Sheteck was significantly higher $(p<0.001)$ among control than cases. About $57 \%$ of cases and $85 \%$ of control were in the habit of wearing Sheteck. Moreover, the duration of 
wearing Sheteck was also significantly higher among controls than cases both for years of wearing and hours per day ( $p$ $<0.001$ ). Finally, table 1, shows that the BMI was significantly higher among cases in comparison to controls $(p<0.002)$.

Table 2, shows that the odds ratio for wearing Sheteck was 0.23 , which was highly significant $(p<0.001)$. Table 3, reveals that the odd ratio of wearing Sheteck among cases with sciatica was 0.038, which was also significant $(p<0.001)$.

\begin{tabular}{|c|c|c|c|c|}
\hline \multicolumn{2}{|l|}{ Criteria } & Cases (149) & Control (100) & $P$-Value \\
\hline \multicolumn{2}{|l|}{ Age } & $51.4 \pm 13.28$ & $59.22 \pm 12.6$ & $<0.001$ \\
\hline \multirow[t]{3}{*}{ Occupation } & Government employee & $35(23.5 \%)$ & $28(28 \%)$ & \\
\hline & Military & $30(20.1 \%)$ & $21(21 \%)$ & 0.663 \\
\hline & Self-employee & $84(56.4 \%)$ & $51(51 \%)$ & \\
\hline \multirow{4}{*}{$\begin{array}{l}\text { Habit of wearing } \\
\text { Sheteck }\end{array}$} & No & $64(42.9 \%)$ & $15(15 \%)$ & $<0.001$ \\
\hline & Yes & $85(57 \%)$ & $85(85 \%)$ & \\
\hline & If How many years & $29.48 \pm 16.43$ & $36.88 \pm 12.75$ & $<0.001$ \\
\hline & Yes How many hours/ day & $7.19 \pm 3.7$ & $9.5 \pm 2.45$ & $<0.001$ \\
\hline \multicolumn{2}{|c|}{ Duration of back pain (years) } & $5.54 \pm 6.17$ & 0 & \\
\hline \multirow{2}{*}{$\begin{array}{l}\text { Radiation of the } \\
\text { pain to the leg }\end{array}$} & Yes & $70(47 \%)$ & 0 & \\
\hline & No & $79(53 \%)$ & 100 & \\
\hline \multirow{3}{*}{$\begin{array}{l}\text { Severity of the } \\
\text { pain }\end{array}$} & Mild & $71(47.6 \%)$ & 0 & \\
\hline & Moderate & $66(44.3 \%)$ & 0 & \\
\hline & Severe & $12(8.1 \%)$ & 0 & \\
\hline \multirow{2}{*}{$\begin{array}{l}\text { Limitation of the } \\
\text { activity }\end{array}$} & Yes & $55(36.9 \%)$ & 0 & \\
\hline & No & $94(63.1 \%)$ & 100 & \\
\hline \multicolumn{2}{|l|}{ BMI } & $25.87 \pm 3.65$ & $24.54 \pm 2.69$ & $<0.002$ \\
\hline \multirow{2}{*}{$\begin{array}{l}\text { Involvement of } \\
\text { sciatica }\end{array}$} & Yes & $64(42.9 \%)$ & 0 & \\
\hline & No & $85(57 \%)$ & 100 & \\
\hline
\end{tabular}

\begin{tabular}{lcccccc}
\hline \multicolumn{6}{c}{ Table 2. Odds Ratio, Chi-square and $\boldsymbol{P}$-Value of wearing Sheteck among cases in comparison to controls } \\
\hline Criteria & & Cases 149 & Control 100 & OR & $\chi^{2}$ & $\boldsymbol{P}$-Value \\
\hline \multirow{2}{*}{ Wearing Sheteck } & Yes & 85 & 85 & & & \\
& No & 64 & 15 & 0.23 & 21.6 & $<0.001$ \\
\hline
\end{tabular}




\begin{tabular}{|c|c|c|c|c|c|c|}
\hline \multicolumn{4}{|c|}{ Duhok Medical Journal } & \multicolumn{3}{|c|}{ Volume 14, Issue 2, 2020} \\
\hline Criteria & & $\begin{array}{l}\text { Cases with } \\
\text { Sciatica }\end{array}$ & $\begin{array}{l}\text { Cases without } \\
\text { sciatica }\end{array}$ & OR & $\chi^{2}$ & $P$-Value \\
\hline \multirow{2}{*}{ Wearing Sheteck } & Yes & 12 & 73 & \multirow{2}{*}{0.04} & \multirow{2}{*}{67.2} & \multirow{2}{*}{$<0.001$} \\
\hline & No & 52 & 12 & & & \\
\hline
\end{tabular}

\section{DISCUSSION}

This is a case-control study when recall basis is considered to be the main limitation. Wearing Sheteck is a habit usually remembered by people as it is part of their traditional clothes. This study found that Sheteck was highly protective of LBP and sciatica. This might be due to the support that Sheteck gave. Almost all cases and controls were wearing Sheteck of Badinani type. This type usually has nodes and the length of material is almost double that of the Sorani one. The results are similar to some other studies which showed some protective effect of supporting belt, but the finding of this study showed a highly significant effect for the protection of LBP and sciatica 20, 21.

This study found about $43 \%$ of the LBP cases were due to sciatica. Whereas a previous study found 55\% of the LBP cases were due to sciatica. 7About $37 \%$ of cases had limitation of movement. Mean age was significantly higher in controls than cases. This will further support the proposed protection of wearing Sheteck, as aging is considered one of the most dependent factors causing chronic LBP due to degeneration of the intervertebral disc. 22 Regarding BMI in cases was significantly higher than controls. Researchers reported that obesity is one of the risk factors for persistent LBP. 23 It has been reported that LBP is also influenced by other factors, which including posture and physical workload 24. In this study, most of the participants in cases were self-employed, including; taxi drivers and workers (about $56.4 \%$ ); the physical work and posture are highly influencing in LBP. 25

Wearing Sheteck was highly protective for LBP significantly with Odd Ratio about (OR 0.23). Moreover, the Sheteck was also significantly highly protective against sciatica among cases with OR about 0.04 . This means that people wearing Sheteck are more than 4 times less liable to develop LBP; while the Sheteck was almost entirely protective from sciatica among cases suffering from LBP. The habit of wearing Sheteck has been present for generations among Kurds. This might have been associated with topography and work in the region. The Kurdish region of Iraq is a mountainous area with villages scatted on mountains and hills. Most of the work among the previous generation was Shepherd and agriculture. Despite the development of roads and the use of cars for transportation, the habit remains among olds as part of their traditional Kurdish clothes. This habit, however, is decreasing in the younger generation due to the globalization of clothes, and its use is limited to celebrations and parties.

In conclusion, the traditional Kurdish belt (Sheteck) is highly protective of LBP and Sciatica. 


\section{REFERENCES}

1. Eklund, A., Jensen, I., LohelaKarlsson, M., Hagberg, J., LeboeufYde, C., et al. Nordic Maintenance Care program: Effectiveness of chiropractic maintenance care versus symptom-guided treatment for recurrent and persistent low back painA pragmatic randomized controlled trial. PloS one. 2018; 13(9): e0203029. doi:10.1371/journal.pone.0203029

2. Zheng, Y. L., Wang, X. F., Chen, B. L., Gu, W., Wang, X., Xu, B., et al. Effect of 12-Week Whole-Body Vibration Exercise on Lumbopelvic Proprioception and Pain Control in Young Adults with Nonspecific Low Back Pain. Medical science monitor: international medical journal of experimental and clinical research. 2019; 25: 443-452. doi:10.12659/MSM.912047

3. Doualla, M., Aminde, J., Aminde, L. N., Lekpa, F. K., Kwedi, F. M., Yenshu, E. V., et al. Factors influencing disability in patients with chronic low back pain attending a tertiary hospital in sub-Saharan Africa. BMC musculoskeletal disorders. 2019; 20(1): 25 . doi:10.1186/s12891-019-2403-9

4. Alnaami, I., Awadalla, N. J., Alkhairy, M., Alburidy, S., Alqarni, A., Algarni, A., et al. Prevalence and factors associated with low back pain among health care workers in southwestern Saudi Arabia. BMC musculoskeletal disorders. 2019; 20(1): 56. doi:10.1186/s12891-019-2431-5

5. Mehling, W.E., Avins, A. L., Acree, M. C., Carey, T. S., \& Hecht, F. M. Can a back pain screening tool help classify patients with acute pain into risk levels for chronic pain? Eur J Pain. 2015; 19(3): 439-446. doi:10.1002/ejp.615

6. Edwards, J., Hayden, J., Asbridge, M., \& Magee, K. The prevalence of low back pain in the emergency department: a descriptive study set in the Charles V. Keating Emergency and Trauma Centre, Halifax, Nova Scotia, Canada. BMC Musculoskeletal Disorders, 2018, doi.org/10.1186/s12891-018-2237-x

7. Konstantinou, K., Dunn, K. M., Ogollah, R., Lewis, M., van der Windt, D., Hay, E. M., et al. Prognosis of sciatica and back-related leg pain in primary care: the ATLAS cohort. The spine journal: official journal of the North American Spine Society. 2018; 18(6); 1030-1040. doi:10.1016/j.spinee.2017.10.071

8. Boote, J., Newsome, R., Reddington, M., Cole, A., \& Dimairo, M. Physiotherapy for Patients with Sciatica Awaiting Lumbar Microdiscectomy Surgery: A Nested, Qualitative Study of Patients' Views and Experiences. Physiotherapy research international: the journal for researchers and clinicians in physical therapy. 2017; 22(3): e1665. doi:10.1002/pri.1665

9. Shipton E. A. Physical Therapy Approaches in the Treatment of Low Back Pain. Pain and therapy. 2018; 7(2): 127-137. doi:10.1007/s40122018-0105-x

10. Wong, A. Y., Karppinen, J., \& Samartzis, D. Low back pain in older adults: risk factors, management options and future directions. Scoliosis 
and spinal disorders. 2017; 12: 14. doi:10.1186/s13013-017-0121-3

11. Sanders, T., Foster, N. E., Bishop, A., \& Ong, B. N. Biopsychosocial care and the physiotherapy encounter: physiotherapists' accounts of back pain consultations. BMC musculoskeletal disorders. 2013; $\quad$ 14: 65 . doi:10.1186/1471-2474-14-65

12. Godfrey, E., Galea Holmes, M., Wileman, V., McCracken, L., Norton, S., Moss-Morris, R., et al. Physiotherapy informed by Acceptance and Commitment Therapy (PACT): protocol for a randomised controlled trial of PACT versus usual physiotherapy care for adults with chronic low back pain. BMJ open. 2016; 6(6): e011548. doi:10.1136/bmjopen-2016-011548

13. Karstens, S., Kuithan, P., Joos, S., Hill, J. C., Wensing, M., Steinhäuser, J., et al. Physiotherapists' views of implementing a stratified treatment approach for patients with low back pain in Germany: a qualitative study. BMC health services research. 2018; 18(1): 214. doi:10.1186/s12913018-2991-3

14. Lyons, K. J., Salsbury, S. A., Hondras, M. A., Jones, M. E., Andresen, A. A., \& Goertz, C. M. Perspectives of older adults on co-management of low back pain by doctors of chiropractic and family medicine physicians: a focus group study. BMC complementary and alternative medicine. 2013; 13: 225. doi:10.1186/1472-6882-13-225

15. Khan, Y., Lawrence, D., Vining, R., \& Derby, D. Measuring biopsychosocial risk for back pain disability in chiropractic patients using the STarT back screening tool: a cross sectional survey. Chiropractic \& Manual Therapies. 2019; doi.org/10.1186/ s12998-018-0228-5

16. Chou, L., Ranger, T. A., Peiris, W., Cicuttini, F. M., Urquhart, D. M., Briggs, A. M., et al. Patients' perceived needs for allied health, and complementary and alternative medicines for low back pain: A systematic scoping review. Health expectations: an international journal of public participation in health care and health policy. 2018; 21(5): 824847. doi:10.1111/hex.12676

17. Anders, C., \& Hübner, A. Influence of elastic lumbar support belts on trunk muscle function in patients with nonspecific acute lumbar back pain. PloS one. 2019; 14(1): e0211042. doi:10.1371/journal.pone.0211042

18. Larivière, C., Caron, J. M., Preuss, R., $\&$ Mecheri, $H$. The effect of different lumbar belt designs on the lumbopelvic rhythm in healthy subjects. BMC musculoskeletal disorders. 2014; 15: 307. doi:10.1186/1471-2474-15-307

19. Calmels P, Queneau P, Hamonet C, Le Pen C, Maurel F, Lerouvreur C, et al. Effectiveness of a Lumbar Belt in Subacute Low Back Pain: An Open, Multicentric, and Randomized Clinical Study. Spine (Phila Pa 1976). 2009;DOI: 10.1097/BRS.0b013e3181 9577dc

20. Rostami M, Noormohammadpour P, Sadeghian AH, Mansournia MA, \& Kordi R. The effect of lumbar support on the ultrasound measurements of trunk muscles: a single-blinded randomized controlled trial. PM R. 
2014 ,

DOI:

10.1016/j.pmrj.2013.09.014

21. Molimard, J., Bonnaire, R., Han, W. S., Convert, R., \& Calmels, P. In-silico pre-clinical trials are made possible by a new simple and comprehensive lumbar belt mechanical model based on the Law of Laplace including support deformation and adhesion effects. PloS one. 2019; 14(3): e0212681.

doi:10.1371/journal.pone.0212681

22. Vo, N. V., Hartman, R. A., Patil, P. R., Risbud, M. V., Kletsas, D., Iatridis, J. C., et al. Molecular mechanisms of biological aging in intervertebral discs. Journal of orthopaedic research: official publication of the Orthopaedic Research Society. 2016; 34(8): 12891306. doi:10.1002/jor.23195

23. Hashimoto, Y., Matsudaira, K., Sawada, S. S., Gando, Y., Kawakami, R., Kinugawa, C. et al. Obesity and low back pain: a retrospective cohort study of Japanese males. Journal of physical therapy science. $2017 ; 29(6)$ : 978-983. doi:10.1589/jpts.29.978

24. Hopayian K, Notley C. A systematic review of low back pain and sciatica patients' expectations and experiences of health care. Spine J. 2014.

25. Hagiwara, Y., Yabe, Y., Yamada, H., Watanabe, T., Kanazawa, K., Koide, M. et al. Effects of a wearable type lumbosacral support for low back pain among hospital workers: A randomized controlled trial. Journal of occupational health. 2017; 59(2): 201209. doi:10.1539/joh.16-0203-OA 


\section{يوخته}

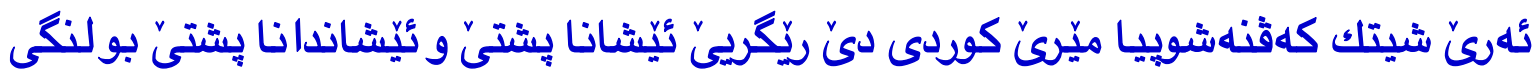 كريت؟ ليّكولينا بويهريّ وكونتولى}

\section{بيّشهى}

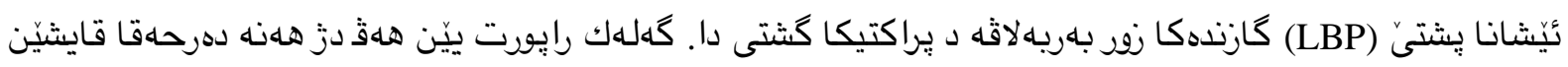

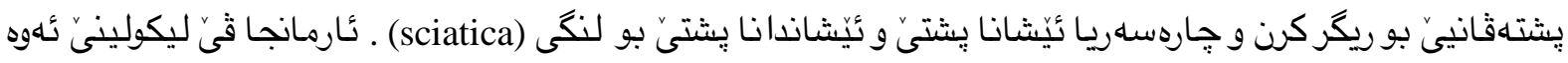

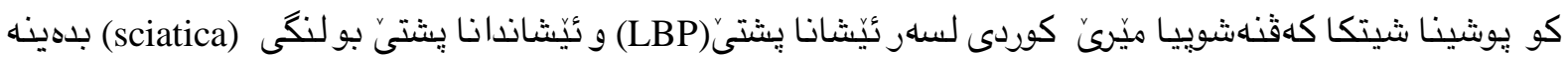
دياركرن.

شَيْواز و نـهنوش

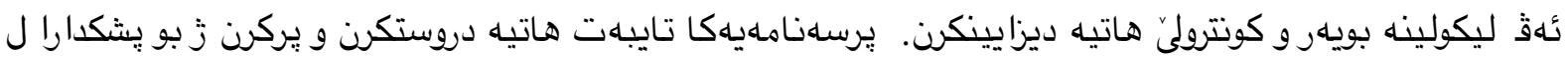

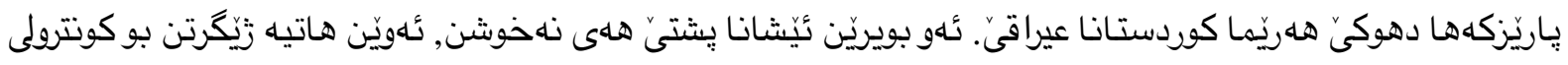

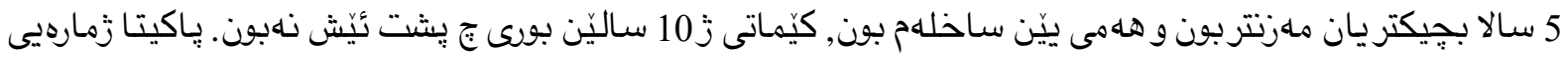
زيو زانيارين جثاكى (SPSS هاتيه بكارئانين زيو ريّكخستنا داتايا. جاركوشا جايى و ريّيا فيشهر هاتنه بكارئينان زيو

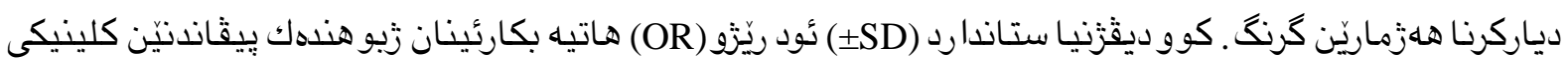

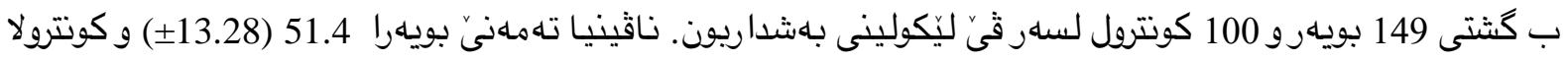

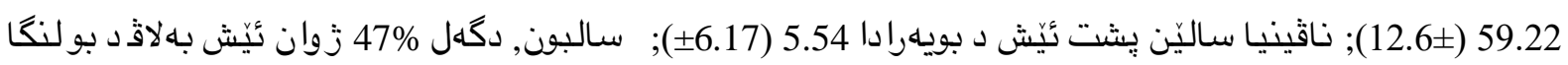

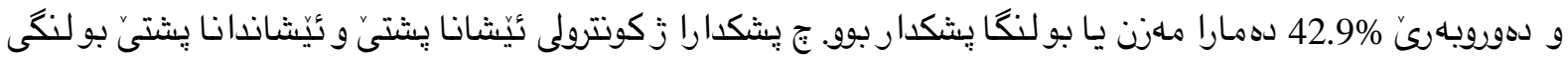

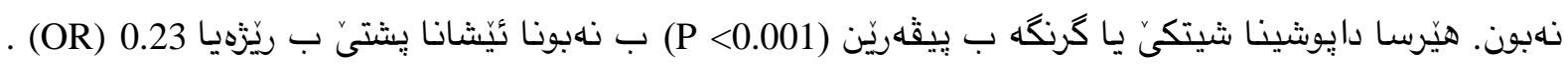

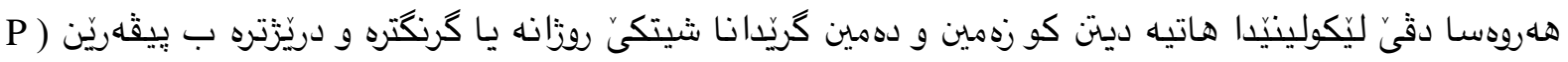

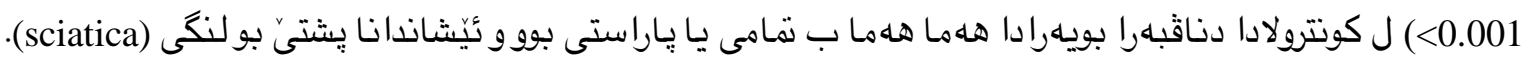

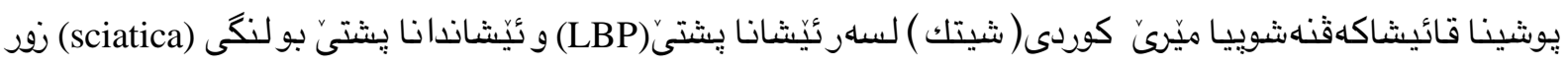




\section{الخلاصة}

هل حزام الذكور الكردي التقليدي هو وقائي من آلام أسفل الظهر وعرق النسا؟: دراسة الحالة والثـاهـ

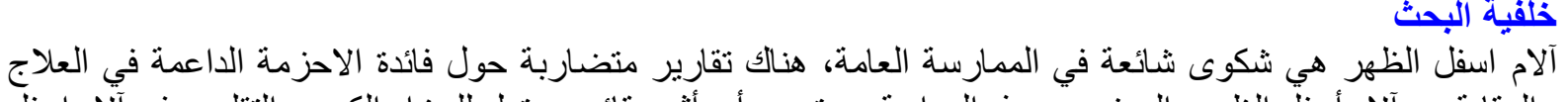

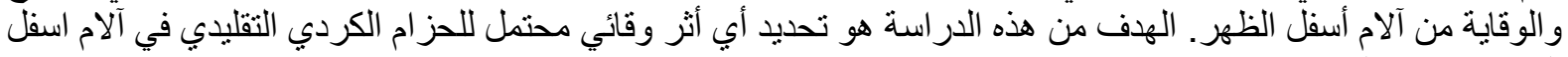
الظهر وعرق النسا.

\section{المرضى وطرق البحث}

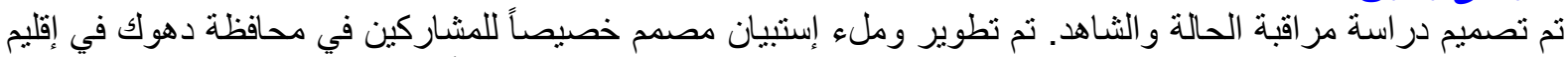

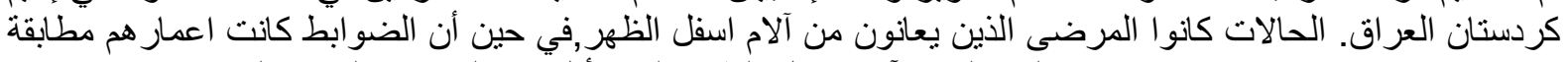

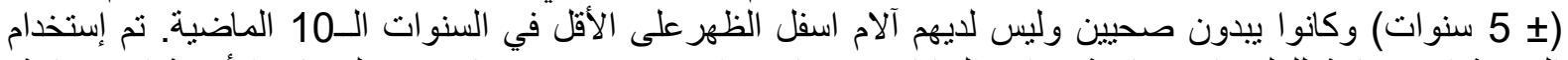

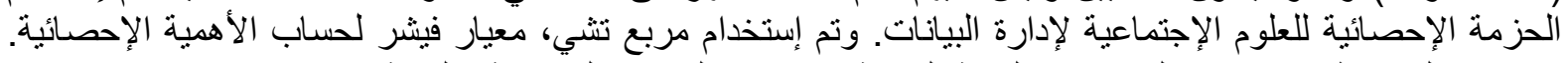

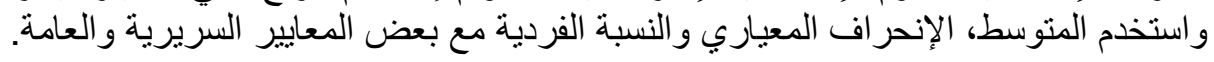

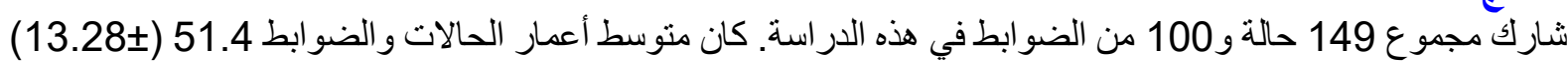

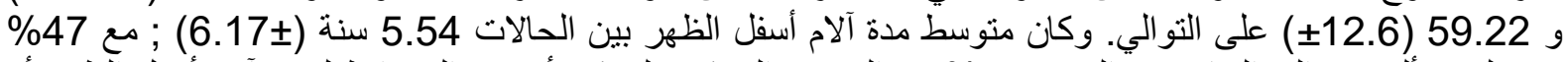

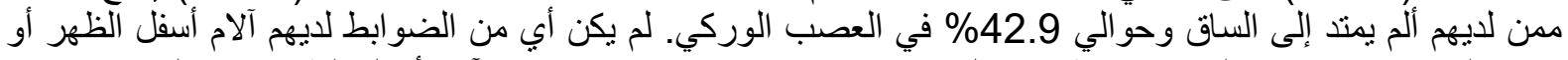
عرق النسا. عادة إرتداء الحز ام إرتبطت بشكل مهم (0.001)

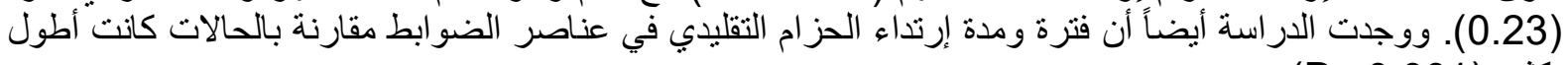
بكثير (P )

الاستتناجات

يعتبر حزام الذكور الكردي التقليدي واقياً للغاية لآلام أسفل الظهر وعرق النسا. كلمات البحث: آلام أسفل الظهر و عرق النسا، حزام داعم (شيتك). 
